\title{
EFEKTIVITAS QUANTUM TEACHING LEARNING PADA MATA PELAJARAN MATEMATIKA SISWA SEKOLAH DASAR
}

\author{
Octarina Hidayatus Sholikhah \\ Universitas PGRI Madiun \\ email: octarinahs@gmail.com
}

\begin{abstract}
The purpose of this research is to examines the effectiveness of quantum teaching learning by comparing the final results between students who use quantum teaching learning and without use quantum teaching learning at elementary school level learning. This research use a quasiexperimental research with a quantitative approach. The research design was Posttest Only Control Group Design by using quantum teaching learning in the experimental group discussion and lecture method in the control group. The population was all students in six grade of SDN Pojoksari academic year 2015/2016. The sampling technique used was cluster random sampling. Data collection methods used in this research is documentation and testing. Analysis data techniques in this research using t-test significance level of 5\%. The result of this research is quantum teaching learning effective applied to elementary school mathematics courses.
\end{abstract}

Keywords : Quantum Teaching Learning, Mathematic Learning

\section{PENDAHULUAN}

Pendidikan merupakan upaya untuk mengembangkan kemampuan individu dalam mengantisipasi kemungkinan-kemungkinan yang sedang atau yang akan terjadi. Pendidikan dilakukan secara terencana, terprogram, terarah dan berkelanjutan sebagai upaya untuk meningkatkan sumber daya manusia dalam menunjang tercapainya tujuan pembangunan nasional. Oleh karena itu, pendidikan harus mampu mempertahankan budaya dan jati diri bangsa di tengah gencarnya gempuran beragam budaya yang beraneka ragam. Karena Indonesia merupakan Negara yang kaya akan budaya dan sumber daya alam, maka Indonesia harus mampu menjadi bangsa yang mandiri yang mampu memenuhi kebutuhan masyarakat sesuai dengan tujuan dan cita-cita bangsa.

Kualitas pendidikan nasional dinilai belum memiliki kualitas yang memadai dibanding dengan kualitas pendidikan di Negara lain. Hal ini dapat dilihat pada peringkat Human Development Index (HDI) Indonesia menempati peringkat 111 dari 117 negara pada tahun 2004 dan peringkat 110 pada tahun 2005. Demikian pula dengan laporan International Educational Achievment (IEA) menunjukkan bahwa kemampuan membaca siswa Sekolah Dasar, Indonesia berada pada urutan 38 dari 39 negara yang disurvei. Sementara dalam laporan World Competitiveness Year Book tahun 2000, sumber daya manusia Indonesia menempati peringkat 46 dari 47 negara yang disurvei.

Pemerintah dalam hal ini Departemen Pendidikan Nasional selalu berusaha agar pendidikan kita dapat berkembang sesuai dengan tuntutan kemajuan jaman, sedangkan masyarakat dan keluarga adalah faktor pendukung berhasil atau tidaknya generasi penerus bangsa untuk memajukan negaranya. Dilihat dari penjelasan tersebut, maka peran pendidikan sangat penting dalam menentukan masa depan bangsa. Pendidikan merupakan 
upaya yang dilakukan secara sadar untuk meningkatkan sumber daya manusia.

Pendidikan dalam ranah pendidikan dasar baik SD/Madrasah Ibtidaiyah, dilakukan untuk memberikan bekal berupa ilmu pengetahuan dan keterampilan untuk mengembangkan cara berpikir (Dirman, 2015: 47). Salah satu alat untuk mengembangkan cara berpikir siswa adalah melalui pelajaran matematika. Karena dalam pembelajaran matematika siswa dituntut untuk mengembangkan potensi berpikir secara logis. Oleh karena itu, matematika sangat diperlukan baik dalam kehidupan sehari-hari maupun dalam menghadapi kemajuan jaman. Sehingga matematika perlu dibekalkan kepada peserta didik sejak SD, bahkan sejak TK (Solikhah, 2014: 737)

Pada kenyataannya prestasi belajar matematika di Indonesia masih rendah. Hal ini dapat dilihat pada survei melalui programme For International Student Assessment (PISA) 2003 menunjukkan bahwa dari 41 negara yang disurvei untuk bidang matematika Indonesia menempati peringkat 39.

Rendahnya prestasi belajar matematika di Indonesia juga dialami siswa SD Negeri yang ada di Kabupaten Magetan. Hal ini dapat dilihat dari hasil wawancara dengan salah satu kepala sekolah di SDN Pojoksari Kabupten Magetan yang menunjukkan bahwa selama proses pembelajaran matematika siswa cenderung ramai sendiri, tidak memperhatikan guru di depan, sampai keefektifan tidak nampak pada proses pembelajaran. Selain permasalahan yang berasal dari siswa ternyata juga ada permasalahan dari tenaga pendidiknya, hal ini terlihat bahwa pada saat proses pembelajaran guru kurang efektif dalam menggunakan model pembelajaran, sehingga kurang menarik perhatian siswa dalam mengikuti pelajaran. Pembelajaran yang digunakan guru hanya bersifat klasikal dengan metode ceramah. Siswa hanya bisa mendengarkan dan mencatat materi yang disampaikan oleh guru tanpa melibatkan siswa secara langsung, sehingga siswa merasa jenuh dan bosan dalam mengikuti pembelajaran. Hal tersebut akan mengurangi tingkat pemahaman siswa terhadap materi yang diajarkan, sehingga berpengaruh terhadap prestasi belajar siswa.

Salah satu penyebab dari berbagai masalah tersebut adalah ketidaktepatan model pembelajaran yang digunakan pada saat pembelajaran matematika. Model pembelajaran yang digunakan guru sangat penting dalam meningkatkan prestasi belajar siswa (Kosasih, 2013). Dalam hal ini kehadiran guru dalam kegiatan pembelajaran memegang peranan penting. Guru harus mampu mengembangkan pengetahuan, pemahaman, dan keterampilan siswa untuk dijadikan bekal dalam menghadapi segala ketimpangan yang terjadi di masyarakat.

Selain itu, guru harus mampu memilih model pembelajaran yang menyenangkan dalam proses pembelajaran, karena model pembelajaran yang tepat dan menarik membuat suasana belajar mengajar menjadi nyaman, sehingga memungkinkan setiap siswa untuk mudah dalam menerima dan menyerap materi pelajaran dengan benar Deporter (2010). Model pembelajaran yang dipilih diharapkan mampu mengembangkan dan meningkatkan prestasi belajar siswa. Ada beberapa model pembelajaran yang bisa digunakan untuk meningkatkan prestasi belajar siswa pada mata pelajaran matematika. Model pembelajaran tersebut diantaranya adalah Quantum Teaching Learning.

Quantum Teaching Learning adalah model pembelajaran yang menyenangkan 
serta menyertakan segala dinamika yang menunjang keberhasilan pembelajaran itu sendiri dan segala keterkaitan, perbedaan interaksi serta aspek-aspek yang dapat memaksimalkan momentum untuk belajar. Quantum Teaching Learning dapat dipandang sebagai model pembelajaran yang ideal, karena menekankan pada kerja sama antara peserta didik dan guru untuk mencapai tujuan bersama. Bobby Deporter (2015), mengembangkan strategi pembelajaran Quantum melalui istilah TANDUR, yaitu Tumbuhkan, Alami, Namai, Demonstrasikan, Ulangi dan Rayakan. Dengan menggunakan model pembelajaran yang tepat, maka diharapkan dapat meningkatkan prestasi belajar siswa pada mata pelajaran matematika. Model pembelajaran Quantum Teaching ini efektif meningkatkan karakter kreatifitas dan hasil belajar Matematika pada siswa kelas III SD Negeri Peterongan (Permana dkk, 2016: 154).

\section{METODE PENELITIAN}

Bentuk penelitian yang digunakan dalam penelitian ini adalah Quasy Experimental Design (Eksperimen semu) dengan rancangan penelitiannya adalah Posttest-Only Control Design yaitu rancangan yang menyertakan kelompok kontrol sebagai pembanding (Sugiyono, 2007). Adapun rancangan penelitian ini dapat digambarkan dengan skema pada tabel 1 .

Tabel 1. Rancangan Posttest-Only Control Design

\begin{tabular}{|c|c|}
\hline $\mathrm{X}$ & $\mathrm{T} 1$ \\
\hline $\mathrm{Y}$ & $\mathrm{T} 2$ \\
\hline
\end{tabular}

Keterangan:

$$
\begin{aligned}
\mathrm{X}= & \text { Perlakuan menggunakan pendekatan } \\
& \text { Quantum Teaching Learning }
\end{aligned}
$$
$\mathrm{Y}=$ Perlakuan tanpa menggunakan pendekatan Quantum Teaching Learning

$T 1=$ Hasil belajar mahasiswa yang diberikan pendekatan Quantum Teaching Learning

$T 2$ = Hasil belajar mahasiswa yang tidak diberikan pendekatan Quantum Teaching Learning

Variabel bebas dalam penelitian ini adalah pendekatan pembelajaran (menggunakan Quantum Teaching Learning dan tanpa menggunakan Quantum Teaching Learning). Variabel terikat dalam penelitian ini adalah hasil belajar siswa kelas VI pada mata pelajaran matematika.

Populasi dalam penelitian ini adalah seluruh siswa VI SDN Pojoksari tahun pelajaran 2015/2016. Pengambilan sampel dalam penelitian ini menggunakan teknik cluster random sampling, maka akan dipilih 2 kelas secara acak. Kelas acakan pertama akan diajarkan menggunakan Quantum Teaching Learning sebagai kelas eksperimen dan kelas acakan kedua akan diajarkan tanpa menggunakan Quantum Teaching Learning sebagai kelas kontrol.

Teknik pengumpulan data dalam penelitian ini menggunakan teknik pengukuran. Pengukuran dilakukan dengan pemberian tes prestasi belajar yakni Ujian Akhir Semester (UAS) mata pelajaran matematika. Soal diberikan sesuai dengan jadwal UAS siswa SDN Pojoksari. Sedangkan, alat pengumpul data atau instrumen penelitian yang digunakan dalam penelitian ini adalah dengan tes. Jenis tes yang dilakukan dalam penelitian ini adalah tes tertulis dalam bentuk pilihan ganda dengan 25 butir soal. Uji validitas meliputi validitas isi dan validitas konstruk melalui judgment 
experts dan validitas butir soal korelasi product moment dari Karl Pearson. Uji reliabilitas menggunakan rumus Alfa Cronbach, uji normalitas menggunakan Kolmogorov-Smirno, uji homogenitas menggunakan Levene's, uji hipotesis menggunakan $U j i-t$ dengan taraf signifikansi $5 \%$.

\section{HASIL DAN PEMBAHASAN}

Penelitian dilakukan dengan terlebih dahulu menguji keseimbangan rata-rata antara kelompok eksperimen dan kelompok kontrol. Uji keseimbangan yang dilakukan menggunakan uji-t. Uji prasyarat untuk uji-t yang dilakukan menunjukkan bahwa masingmasing kelompok perlakuan berasal dari populasi yang berdistribusi normal dan memiliki variansi yang sama,

Sedangkan uji-t yang dilakukan menunjukkan bahwa rerata kemampuan awal dari kedua kelompok perlakuan adalah sama (seimbang). Dengan demikian dapat disimpulkan bahwa masing-masing kelompok perlakuan layak untuk diberikan perlakuan.

Tabel 2. Rangkuman Rata-Rata Prestasi Belajar Matematika

\begin{tabular}{lcccc}
\hline \multirow{2}{*}{$\begin{array}{c}\text { Model } \\
\text { Pemb }\end{array}$} & Jumlah & \multicolumn{3}{c}{ Nilai } \\
\cline { 3 - 5 } & siswa & Terendah & Tertinggi & $\begin{array}{c}\text { Rata- } \\
\text { rata }\end{array}$ \\
\hline Kontrol & 15 & 52.00 & 76.00 & 65,38 \\
\hline Eksperimen & 17 & 52.00 & 80.00 & 70,00 \\
\hline
\end{tabular}

Selanjutnya dilakukan uji hipotesis penelitian menggunakan uji-t yang sebelumnya ada uji prasyarat yang menunjukkan bahwa sampel berasal dari populasi berdistribusi normal dan memiliki variansi yang sama yang ditunjukkan pada Tabel 3 .
Tabel 3. Rangkuman Uji Prasyarat

\begin{tabular}{lcccc}
\hline \multicolumn{1}{c}{ Uji } & Jenis Uji & Hasil & Keputusan & Kesimpulan \\
\hline $\begin{array}{l}\text { Normalitas } \\
\text { Kontrol }\end{array}$ & Lilliefors & 0,156 & $\begin{array}{c}\mathrm{H}_{0} \\
\text { diterima }\end{array}$ & Data normal \\
\hline $\begin{array}{l}\text { Normalitas } \\
\text { Eksperimen }\end{array}$ & Lilliefors & 0,136 & $\begin{array}{c}\mathrm{H}_{0} \\
\text { diterima }\end{array}$ & Data normal \\
\hline Homogenitas & Barlett & 1.31 & $\begin{array}{c}\mathrm{H}_{0} \\
\text { diterima }\end{array}$ & $\begin{array}{c}\text { Data } \\
\text { Homogen }\end{array}$ \\
\hline
\end{tabular}

Hipotesis uji-t sebagai berikut:

$\mathrm{H}_{0}: \mu_{1} \leq \mu_{2}$ (prestasi belajar matematika menggunakan model Quantum Teaching Learning tidak lebih baik dari pada yang tidak menggunakan Quantum Teaching Learning)

$\mathrm{H}_{1}: \mu_{1}>\mu_{2}$ (prestasi belajar matematika menggunakan model Quantum Teaching Learning lebih baik dari pada yang tidak menggunakan Quantum Teaching Learning)

Uji hipotesis diperoleh hasil $t_{o b s}=2,799$ dan $t_{\text {tabel }}=1,960$. Ini berarti $\mathrm{H}_{0}$ ditolak, sehingga disimpulkan bahwa prestasi belajar matematika menggunakan model Quantum Teaching Learning lebih baik dari pada yang tidak menggunakan model Quantum Teaching Learning. Hal ini sesuai dengan hipotesis yang disusun.

Siswa yang diberikan model pembelajaran Quantum Teaching Learning dan tidak diberikan model pembelajaran Quantum Teaching Learning memiliki prestasi belajar yang berbeda. Hal ini dapat dilihat dari nilai rata-rata yang diperoleh siswa. Siswa yang diberikan model pembelajaran Quantum Teaching Learning memiliki rata-rata 84,75 dan yang tidak diberikan Quantum Teaching Learning memiliki rata-rata 76,56. Dari nilai rata-rata yang diperoleh dapat diketahui bahwa prestasi belajar siswa yang diberikan pembelajaran dengan model pembelajaran Quantum 
Teaching Learning lebih baik daripada yang tidak diberikan Quantum Teaching Learning. Hal ini disebabkan karena pada pembelajaran Quantum Teaching Learning siswa akan lebih mudah dan lebih fokus perhatianya pada materi yang disampaikan dan berusaha memahaminya, sehingga pembelajaran berjalan aktif dan efektif. Hal ini diperkuat lagi oleh jurnal penelitian yang telah diujikan oleh Trisnawati dan Wutsqa (2015: 305) mengemukakan bahwa model pembelajaran Quantum Teaching lebih efektif daripada cooperative Learning tipe Teams Games Tournament (TGT) dalam pembelajaran matematika.

\section{SIMPULAN}

Quantum Teaching Learning efektif diterapkan pada mata pelajaran matematika terbukti dari hasil uji yang diperoleh sebesar $t_{o b s}=2,799$ dengan taraf signifikansi sebesar $5 \%$. Hasil belajar siswa yang diajarkan menggunakan Quantum Teaching Learning lebih baik daripada hasil belajar siswa yang tidak diajarkan dengan Quantum Teaching Learning dengan rata-rata 84,75 pada kelas ekperimen dan 76,56 pada kelas kontrol.

\section{DAFTAR PUSTAKA}

Deporter Bobbi, Mark Reardon dan Sarah Singer-Nourie. 2010. Quantum Teaching. Bandung: Kaifa 34.

Deporter Bobbi dan Mike Hernacki. 2015. Quantum Learning. Bandung: Mizan Pustaka.

Dirman dan Cicih Juarsih. 2014. Pengembangan Potensi Peserta Didik. Jakarta: Rineka Cipta.

Kosasih, Nandang dan Dede Sumarna. 2013. Pembelajaran Quantum dan Optimalisasi Kecerdasan. Bandung: Alfabeta.

Permana, dkk. 2016. Keefektifan Pembelajaran Quantum Teaching Terhadap Kreatifitas dan Hasil Belajar Matematika Kelas III SDN Peterongan Semarang. Jurnal Profesi Pendidikan Dasar Vol. 3, No. 2, 2016, p. 154. http://journals.ums.ac.id/index.php/ppd/article/view/3968/3515

Solikhah, Octarina Hidayatus. 2014. Eksperimentasi Model Pembelajaran Kooperatif Tipe Group Investigation (GI) dan Numbered Heads Together (NHT) pada materi Garis Singgung Lingkaran Ditinjau dari Kecerdasan Majemuk Siswa Kelas VIII SMP Negeri Se-kota Madiun Tahun Ajaran 2013/2014. Jurnal Riset Pendidikan Matematika. 7 (2): 737.

Sugiyono. 2015. Metode Penelitian Kuantitatif Kualitatif dan R\&D. Bandung: Alfabeta.

Trisnawati dan Dhoriva Urwatul Wutsqa. 2015. Perbandingan Keefektifan Quantum Teaching dan TGT pada Pembelajaran Matematika Ditinjau dari Prestasi dan Motivasi. 2 (2): 305. 